\title{
Bloom's Taxonomy and Flipped Classroom.
}

\section{La Taxonomía de Bloom y el Aula Invertida.}

Martha Lucía Lara Freire ${ }^{1}$, Mercedes Leticia Lara Freire ${ }^{2}$, Wilson Gonzalo Rojas Yumisaca ${ }^{3}$, Mayra Rosana Rojas Yumisaca ${ }^{4}$.

Recibido: 10-06-2019 / Revisado: 15-07-2019 /Aceptado: 15-08-2019/ Publicado: 06-09-2019

\begin{abstract}
.
DOI: https://doi.org/10.33262/cienciadigital.v3i3.3.797

The objective of this study was to establish the effectiveness of the flipped classroom to improve the high order thinking skills in the Bloom's taxonomy. This was a qualiquantitative research which involved collecting and converting data into numerical form, it was also a quasi-experimental research and the population were Fourth Level English Students from the English Center at Escuela Superior Politécnica de Chimborazo. The applied instruments were initial and satisfaction survey and a pre and post tests. The sample was chosen at random and the groups were previously established. The scientific, inductive, deductive and descriptive methods were applied during three months intervention. For analyzing the results this procedure was followed; organization of the information, pre-test results analysis, analysis of the collected evidences, post-test, analysis, tables, charts, and graphs design, statistical results analysis, hypothesis tendencies and drawn of conclusions. Finally, it was concluded that the flipped classroom activities in the English as a Foreign Language classroom improved students high order thinking skills.
\end{abstract}

\footnotetext{
1 Escuela Superior Politécnica de Chimborazo, Facultad de Salud Pública. Riobamba, Ecuador. mlaraf@espoch.edu.ec

${ }^{2}$ Escuela Superior Politécnica de Chimborazo, Facultad de Informática y Electrónica. Riobamba, Ecuador. leticia.lara@espoch.edu.ec

${ }^{3}$ Escuela Superior Politécnica de Chimborazo, Facultad de Gestión del Transporte. Riobamba, Ecuador. wilson.rojas@espoch.edu.ec

4 Unidad Educativa Combatientes de Tapi, Área de Lengua Extranjera. Riobamba, Ecuador. rosana.rojas@educacion.gob.ec
} 
Keywords: Flipped Classroom, Bloom's Taxonomy, English as a Foreign Language, Improvement.

\section{Resumen.}

El objetivo de este estudio fue establecer la efectividad del aula invertida para mejorar las habilidades de pensamiento de orden superior en la Taxonomía de Bloom. Esta fue una investigación cuali-cuantitativa que involucró la recopilación y conversión de datos en forma numérica, también fue una investigación cuasiexperimental y la población estuvo conformada por estudiantes de inglés de cuarto nivel del Centro de Inglés de la Escuela Superior Politécnica de Chimborazo. Los instrumentos aplicados fueron: encuesta inicial, encuesta de satisfacción, una prueba previa y una prueba posterior. La muestra se eligió al azar y los grupos estuvieron previamente establecidos. Los métodos científicos, inductivos, deductivos y descriptivos se aplicaron durante la intervención, misma que se desarrolló durante tres meses. Para analizar los resultados se siguió este procedimiento: organización de la información, análisis de resultados de la prueba inicial, análisis de las evidencias recopiladas, análisis de la prueba posterior, diseño de tablas, cuadros y gráficos, análisis de resultados estadísticos, tendencias de la hipótesis y conclusiones extraídas. Finalmente, se concluyó que las actividades de aula invertida en el aula de inglés como Lengua Extranjera mejoraron las habilidades de pensamiento de orden superior de los estudiantes.

Palabras clave: Aula Invertida, Taxonomía de Bloom, Inglés como Lengua Extranjera, Mejoramiento.

\section{Introduction}

High order thinking skills are the ability an individual has to plan a strategy to get information. It also makes people conscious about every step and the strategies to follow during the process to solve problems and evaluate one's own knowledge productivity (Crossland, 2015).

These skills include critical, logical, reflective, metacognitive, and creative thinking. They are activated when individuals encounter unfamiliar problems, uncertainties, questions, or dilemmas. Successful applications of the skills result in explanations, decisions, 
performances, and products that are valid within the context of available knowledge and experience that promote continued growth in these and other intellectual skills. Higher order thinking skills are grounded in lower order skills such as discriminations, simple application and analysis, and cognitive strategies and are linked to prior knowledge of subject matter content. Appropriate teaching strategies and learning environments facilitate their growth as do student persistence, self-monitoring, and open-minded, flexible attitudes (Rhashvinder, 2018).

According to the National English Curriculum regulations and expectations regarding English learning in Ecuador have changed, but changes are not always considered easy or possible (Cronquist \& Fiszbein, 2017).

One of the aims of the English language learning reform launched in 2012 was to create opportunities for a broader cross-section of students to study at top-ranking universities around the world (Council, 2015).

As reported by the International Commission on Education, Equity, and Economic Competitiveness in Latin America and the Caribbean enrollment has increased rapidly and significantly over the past three decades, the equality of education has declined in the same proportion (Torres, 2007). The teaching of language is very poor in most countries. Few students develop appropriate skills in the areas of critical thinking, problem solving and decision making (Mabunda, 2014). In an era when good schools are increasingly crucial to economic development, Latin America is falling behind and the situation in Ecuador is consistent.

Another interesting fact is that by 2001, the country had achieved universal primary education, but academic performance has remained low and has even declined in the past decade (UNESCO, 2015).As far as the language material tested, students in all grades knew an average of 60 percent or less (Carrillo, Onofa, \& Ponce, 2010).

The Escuela Superior Politécnica English Center was founded in 1974 with the objective of increasing the possibilities to apply the knowledge in the teaching-learning of languages such as English, in all the professional fields, under an institutional-academic excellence paradigm 
with scientific, technological and humanistic permanent innovation in a global world. Then, it is the teacher-researcher job to guarantee that this objective is being fulfilled. Students must be ready to face real life situations, using English as the necessary tool in the $21^{\text {st }}$ century.

The English Center offers a program of six levels of English directed to students from different Faculties, and all teachers must follow the same curriculum which is mostly grammar-based, according to Level Fourth syllabus, at the end of the semester students should be able to: apply critical thinking, use English to solve problems related to the students' major, choose the best resources in problem solving, express ideas, opinions, and feelings adequately, design their critical thinking process in their learning habits, and discuss current, national and international events related to the major.

Furthermore, the Article 34 of the Academic Regulation Regimen states that students must demonstrate their outcome by taking a proficiency test once they have approved $60 \%$ of their career program (Jiméneza, Rodríguez, \& Rey, 2017).

Nevertheless, none of the outcomes have been evaluated or proved to be fulfilled, due to the syllabi format classes continue to be traditional, where grammar rules or lectures are developed in class and practical activities are sent as homework, ending up in a limited opportunity for students to achieve the goals, since teachers do not use the class time for inferential thinking or discussion activities, which are two of many tools which could be used to foster high order thinking skills.

Even though, the students' learning outcomes included in the syllabus are based on Bloom's Taxonomy, the activities developed in class are not correctly directed to improve high order thinking skills. Then the first problem to be solved is to implement a new method which contributes to students' holistic training in a global world.

The second detected problem is the ability to become independent learners. The National Curriculum Guidelines for English as a Foreign Language proposed by the Ministerio de Educación del Ecuador published on August 2004 states that "Language techniques are designed to engage learners in the authentic, functional use of language for meaningful 
purposes". Unfortunately, this statement does not apply to our surrounding; students in Level Fourth at the English Center are not independent learners.

Finally, it is well known that students are highly identified with technology and spend a considerable amount of time working online. The English Center provides a Virtual Learning Environment which allows creating online activities and enrolling students in them. Inside the course various resources such as quizzes, questionnaires, structured lessons and forums can be combined, but teachers are not taking advantage of this tool to train students in high order thinking activities as discussion forums.

For all the reasons exposed above the proposal is to implement the flipped teaching method in order to dedicate more time to practical (high order thinking skills) activities in class and work on the lecture at home through grammar videos recorder by the teacher. In order to improve high order thinking skills, lessons are planned which include how to work with the videos, activities mostly focused on inferential thinking and online discussions, and how to take advantage of the Virtual Learning Environment and in this way also foster independent learners.

\section{Materials and Methods}

This project was developed by applying the quali-quantitative research. This is a common approach and helps to 'triangulate' i.e. to back up one set of findings from one method of data collection underpinned by one methodology, with another very different method underpinned by another methodology - for example, you might give out a questionnaire (normally quantitative) to gather statistical data about responses, and then back this up and research in more depth by interviewing (normally qualitative) selected members of your questionnaire sample (Arias, 2012).

The qualitative research involves collecting and converting data into numerical form so that statistical calculation can be made and conclusions drawn and qualitative research is about recording, analyzing and attempting to uncover the deeper meaning and significance of human behavior and experience, including contradictory beliefs, behaviors and emotions (Grover, 2015). 
This was a quasi-experimental design, because it includes selecting groups, the experimental and the control one.

A quasi-experimental design is simply defined as not a true experiment. This design does not have randomly assigned groups.

The population was Level Fourth students from the Escuela Superior Politécnica de Chimborazo.

For this research four different methods were applied: the scientific method to identify the problem in the English Center at Escuela Superior Politécnica de Chimborazo, with the purpose of implementing a different method from the traditional one and improve Level Fourth students' high order thinking skills. The deductive method to deduct general facts and identify specific ones, for this research the related problems were considered to work on practical class activities, inferential thinking and discussion activities and finally determine the existing problems in the English language teaching in the English Center at Escuela Superior Politécnica de Chimborazo. The inductive method by applying the pre-test and posttest, the specific problems of each student were identified to generalize the facts and phenomena through which possible solutions will be found to improve the current problem. The descriptive method through a logical process, it started with the facts and phenomena description about the formulated problem. Then the data obtained through the initial survey was tabulated and finally, the results of the pre-test and post-test applied to the Level Fourth students will be analyzed.

For data collection the following instruments were used: survey application to verify the presence of the problem, pre-test application, design and application of inferential reading and online group discussion strategies, post-test application, and satisfaction survey application.

The results analysis techniques and procedures are: organization of the information, pre-test collected information analysis, analysis of the evidences collected from the students during the proposal implementation, post-test analysis, tables, charts and graphs design, statistical results analysis looking for objectives and hypothesis tendencies and drawn of conclusions. 


\section{Results}

The three specific hypotheses as well as the general hypothesis were accepted and proved. For the analysis of results the Chi-square and $t$-student tests were applied. According to the data gathered during the intervention for the control and experimental groups and by interpreting the grades students obtained before and after the intervention it could be proved that the flipped teaching method improves high order thinking skills development since the final grade for the control group was 2,68 / 10,00 and for the experimental group 7,00 / 10,00.

\section{Table 1. Control and Experimental Groups Post-Test Results}

\begin{tabular}{lcc}
\hline \multicolumn{1}{c}{ Group } & Average & Percentage \\
\hline Control & 2,68 & $26,80 \%$ \\
Experimental & 7,00 & $70,00 \%$ \\
\hline
\end{tabular}

Source: Post-Test results

Author: Martha Lara

\section{Discussion}

The flipped teaching method has mostly been applied in science. Cheryl Morris in her blog dedicated to help English teachers posted: "For people who want to flip science or math, there are a wealth of resources available, but in English there are not many people flipping and writing about it. I think it is partially a problem of definition; there aren't many people who can define what English flipping looks like" (Thomasson, 2012).

In Chapter 10, English was made to flip, of the book "Flipped Learning: Gateway to Student Engagement" Bergmann and Sams focus on English Teacher April Gudenrath and her story as she adopted flipped teaching and learning (Sams, 2014).

This particular research results have not been analyzed yet, but based on observation it could be said that student feel challenged to try new methods and techniques which foster selflearning and high order thinking skills development specially because flipped teaching is part of blended learning and students like to work with technology and at their own pace. By recording the grammar videos the researcher is providing students with a very practical tool, since they can watch them as many times as needed and in their home time. 
Then, it can be concluded that by applying the flipped teaching method, first, students become conscious about the importance of self-study. Second, students develop improve high order thinking skills and specifically inferential thinking through reading. Third, through the use of a Virtual Leaning Environment, students learn to be part of their knowledge building and enjoy participating actively in online discussions and they can also apply all the content worked on during the time of the proposal application. Finally, students are open to new alternatives to improve their high order thinking skills and English level.

\section{Conclusions}

- The implementation of the flipped classroom in the English as a Foreign Language with activities which gave more emphasis to the high order thinking skills in the Bloom's Taxonomy proved to be effective to obtain a notorious improvement in the students' academic performance; not only because their grades were higher at the end of the intervention, but also because it was possible to foster analyzing, evaluating, and creating.

- In addition, one of the characteristics of the flipped classroom is that students do not take homework at home, they do homework in the classroom; therefore, the teacher is able to monitor students task accomplishment and give immediate feedback and this fact played an important role in student's outcomes.

\section{Referencias Bibliográficas}

Arias, F. (2012). El proyecto de Investigación 6ta Edición. Editorial Episteme.

Carrillo, P., Onofa, M., \& Ponce, J. (2010). Information Technology and Student Achievement. En Evidence from a Ramdomized study in Ecuador. Quito.

Council, T. B. (Mayo de 2015). Education Intelligence. Obtenido de English in Ecuador: https://ei.britishcouncil.org/sites/default/files/latin-americaresearch/English\%20in\%20Ecuador.pdf

Cronquist, K., \& Fiszbein, A. (2017). English Language Learning in Latin America. The Dialogue Leadership for the Americas. 
Crossland, J. (December de 2015). Academia.edu. Obtenido de https://www.academia.edu/19515817/Thinking_Skills_and_Blooms_Taxonomy

Grover, V. (2015). Research approach: An overview. ResearchGate. Obtenido de http://www.alzheimer-europe.org/Research/Understanding-dementia-research/Types-ofresearch/The-four-main-approaches

Jiméneza, M., Rodríguez, C., \& Rey, L. (2017). Standardized Test Results: An Opportunity for English Program Improvement. Scielo.

Mabunda, E. (2014). How can we promote critical thinking skills across learning areas in our classrooms? ResearchGate.

Rhashvinder, S. (2018). A Review of Research on the Use of Higher Order Thinking Skills . International Journal of English Linguistics .

Sams, J. B. (2014). Flipped Learning: Gateway to Students Engagement . United States of America: International Society for Technology in Education.

Thomasson, C. M. (Junio de 2012). TMI Flipps English . Obtenido de http://www.morrisflipsenglish.com/blog-ion-lucidity/what-it-means-to-flip-english

Torres, C. A. (2007). Comparative Education. En C. A. Torres, The Dialect of the Global and Local (pág. 448). Washington: Rowman \& Littlefield Publishers.

UNESCO. (2015). The State of Education in Latin America and the Caribbean. Obtenido de http://www.unesco.org/new/fileadmin/MULTIMEDIA/FIELD/Santiago/pdf/state-ofeducation-in-LAC-towards-2015.pdf 


\section{PARA CITAR EL ARTÍCULO INDEXADO.}

Lara Freire, M., Lara Freire, M., Rojas Yumisaca, W., \& Rojas Yumisaca, M. (2019). Bloom's Taxonomy and Flipped Classroom. Ciencia Digital, 3(3.3), 210-219.

https://doi.org/10.33262/cienciadigital.v3i3.3.797

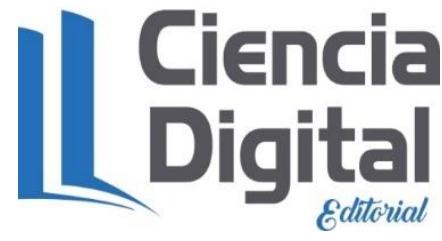

El artículo que se publica es de exclusiva responsabilidad de los autores y no necesariamente reflejan el pensamiento de la Revista Ciencia Digital.

El artículo queda en propiedad de la revista y, por tanto, su publicación parcial y/o total en otro medio tiene que ser autorizado por el director de la Revista Ciencia Digital.
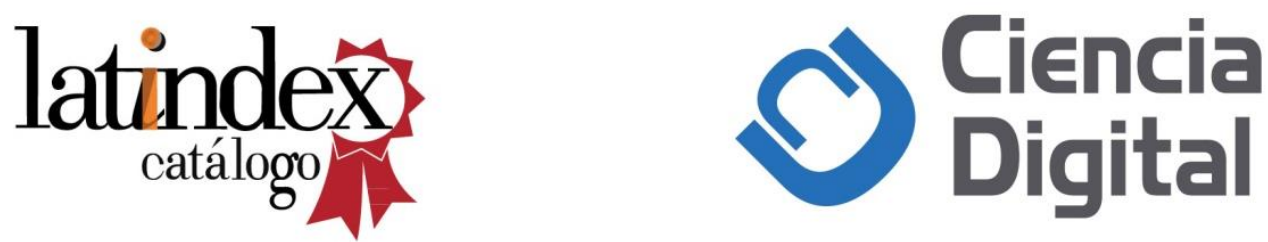